\title{
CD4 and CD8 Count in Breast Cancer Patient Undergoing Post-Surgery FAC Protocol
}

\author{
Dr. Abdullah Al Mueed Khan ${ }^{1 *}$, Dr. Jobaida Naznin ${ }^{2}$, Dr. Shantanu Das ${ }^{3}$, Prof. Dr. Osul Ahmed Chowdhury ${ }^{4}$
}

${ }^{1}$ House Staff, Department of Cardiology, National Institute of Cardiovascular Disease \& Hospital, Dhaka, Bangladesh

${ }^{2}$ Assistant Professor, Department of Endocrinology, Shaheed Suhrawardy Medical College and Hospital, Dhaka, Bangladesh

${ }^{3}$ Assistant Professor, Department of Microbiology, Sylhet MAG Osmani Medical College, Sylhet, Bangladesh

${ }^{4}$ Principal and Professor (Retd.), Department of Microbiology, Sylhet MAG Osmani Medical College, Sylhet, Bangladesh

DOI: $10.36347 /$ sjams.2020.v08i11.026

| Received: 17.10.2020 | Accepted: 02.11.2020 | Published: 20.11.2020

*Corresponding author: Dr. Abdullah Al Mueed Khan

Abstract

Original Research Article

Objective: In this study our main goal is to evaluate the CD4 and CD8 count in breast cancer patient undergoing postSurgery FAC protocol. Method: This quasi-experimental study was carried out at Dept. of Microbiology, Department of radiotherapy \& Department of Surgery, Sylhet MAG Osmani Medical College Hospital from January, 01,2011 to December, 31, 2011. Samples from the 30 cases were collected, first from Department of surgery (before operative procedure) and then, from Department of radiotherapy (after surgery and 3 cycles of adjuvant chemotherapy) from the same patient. Results: During the study, left breast was involved in 17 (53.3\%) patients and right breast was involved in $13(43.3 \%)$ patients. Regarding histological grading was grade-II in 13 (43.3\%) cases, grade-I in 11 (37.7\%) and grade-III in $6(20.0 \%)$ cases.CD4+T cell count before chemotherapy was $1023.4 / \mathrm{uL}$ (SD \pm 320.7$)$ and CD4+T cell count after chemotherapy was $540.7 / \mathrm{uL}(\mathrm{SD} \pm 266.1)$. CD4+T cell count was significantly reduced after chemotherapy $(\mathrm{z}=9.164 ; \mathrm{p}<0.001)$. Conclusion: from our study we conclude that, CD4 and CD8+ T cell number and their ratio as an assessment of immune function status in breast cancer patients, before and after surgery and adjuvant chemotherapy with the intention of delineating any potential immune aberrations that may result from therapy.

Keywords: breast cancer, CD4/CD8 ratio, chemotherapy.

Copyright (C) 2020 The Author(s): This is an open-access article distributed under the terms of the Creative Commons Attribution 4.0 International License (CC BY-NC 4.0) which permits unrestricted use, distribution, and reproduction in any medium for non-commercial use provided the original author and source are credited.

\section{INTRODUCTION}

Breast cancer incidence and mortality rates remain highest in developed countries compared with developing countries. The incidence is high in North America and Northern European countries, intermediate in Southern European and Latin American countries and low in most Asian and African countries [1]. In the western world breast cancer accounts for $27 \%$ of all female cancer and one out of fourteen can expect to develop breast cancer in their life time [2].

In the United States, each year approximately 100,000 new cases are diagnosed and approximately 30,000 patients die of the disease [3]. However, in some regions of the world (North America, Western Europe and Australia) breast cancer mortality is finally beginning to fall, presumably because of the combined action of earlier diagnosis and improved therapy [4].

In countries like India, Japan (though developed), China and those of Africa, the highest recorded incidence rates from the various regional registries for the year 1990, are 23.5, 33.4, 26.5 and 29.5 per 100,000 respectively; which are more than $50 \%$ lower than the few 'low' rates of high-risk populations. Despite the low incidence rates, almost $40 \%$ of the 1990 global cancer burden and $45 \%$ of deaths due to the disease occurred in the developing countries. In India it is the second most common cancer after cervix, accounting for $19 \%$ of the total cancer burden in women. The incidence rate in Asian women has been rising and is associated with a shift towards a more westernized lifestyle. The Bombay Cancer registry has also recorded a consistent rise in the incidence of breast cancer, which has now overtaken cervical cancer, to be the leading cancer in women of Mumbai [5].

In this study our main aim is to evaluate CD4 and CD8 count in breast cancer patient undergoing post-Surgery FAC protocol. 


\section{OBJECTIVE}

\section{General objective}

- To evaluate CD4 and CD8 count and their ratio in breast cancer patient undergoing postSurgery FAC protocol.

\section{Specific objective}

- To detect CD8+T cell count before and after chemotherapy.

- To identify histological grading of the patients.

\section{Methodology}

Study type: This was a quasi-experimental study.

Place and period of study: This study was carried out at Dept. of Microbiology, Department of radiotherapy \& Department of Surgery, Sylhet MAG Osmani Medical College Hospital from January, 01, 2011 to December, 31, 2011.

Sampling technique: Purposive sampling

\section{Inclusion Criteria}

All female diagnosed patients of breast carcinoma -

- Of 25-65 years of age.

- Planned for adjuvant FAC protocol after surgery.

\section{Exclusion Criteria}

- H/o any complication in breast surgery, which causes delayed wound healing.

- Malignancy complicated with other chronic diseases.

- H/o any immunosuppressive disease, like DM, Rheumatoid arthritis.

- Patients not willing to participate in the study.

- H/O taking any myeloid growth factors (Granulocyte colony stimulating factor, granulocyte-macrophage colony stimulating factor).

\section{Study Design}

- A total number of thirty breast cancer patients were enrolled for the study, and from them consecutive two blood samples were taken. The first sample was taken before surgery, when they were admitted into surgery ward. And the next sample was taken after surgery and the third cycle of the scheduled six cycled adjuvant FAC ( 5-Fluouracil, Adriamycin, Cyclophosphamide) protocol chemotherapy .Samples were selected purposively, according to inclusion and exclusion criteria.

\section{Data Collection Procedure}

Samples from the cases were collected, first from Department of surgery (before operative procedure) and then, from Department of radiotherapy (after surgery and 3 cycles of adjuvant chemotherapy) from the same patient. Prior ethical permission was obtained from the E.C. of Sylhet MAG Osmani Medical College. Written informed consent was obtained from each patient Detailed history from the patient was taken.

\section{Statistical Analysis}

All data will be checked and analyzed with the help of SPSS (statistical package for social sciences) with version 12.0. Statistical significance will be calculated using paired $\mathrm{T}$ test.

\section{RESULTS}

In table-1 shows age distribution of the patients where $14(46.7 \%)$ patients were in the age group of 41 to 50 years, $9(30.0 \%)$ patients were in the age group of 31 to 40 years, $4(13.3 \%)$ patients were in the age group of 51 to 60 years, $2(6.7 \%)$ patients were in the age group up to 30 years and $1(3.3 \%)$ patient was in the age group above 60 years. The following table is given below in detail:

Table-9: Distribution of respondents by age group $(n=30)$

\begin{tabular}{|l|c|c|}
\hline Age group & Frequency & Percentage \\
\hline$\leq 30$ years & 2 & 6.7 \\
\hline 31-40 years & 9 & 30.0 \\
\hline 41-50 years & 14 & 46.7 \\
\hline 51-60 years & 4 & 13.3 \\
\hline$>60$ years & 1 & 3.3 \\
\hline
\end{tabular}

In figure-1 shows distribution of patients according to side of involvement. Left breast was involved in $17(53.3 \%)$ patients and right breast was involved in $13(43.3 \%)$ patients. The following table is given below in detail: 


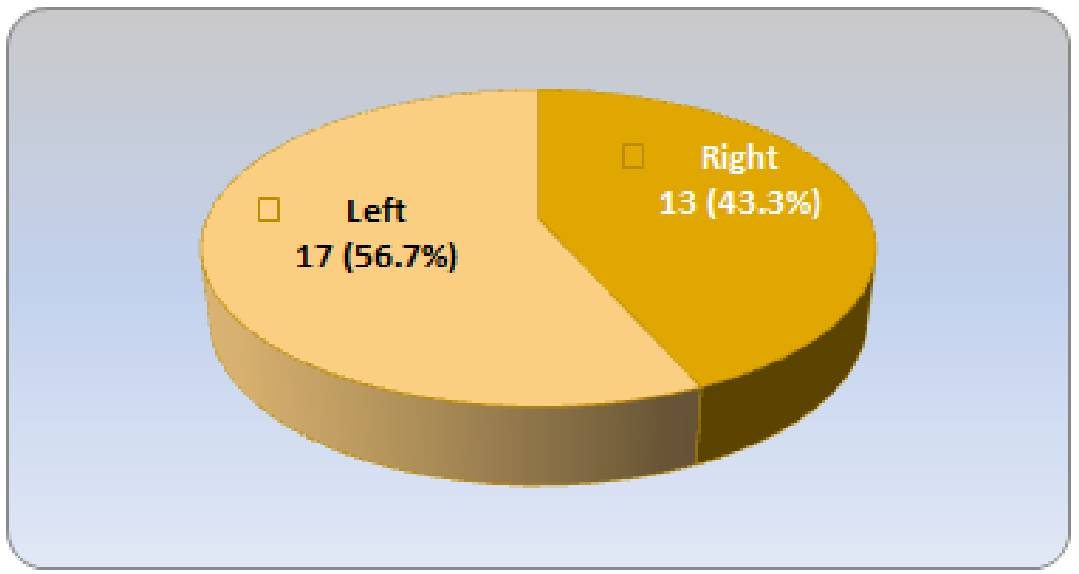

Fig-1: Distribution of patients according to side of involvement $(n=30)$

In figure-2 shows distribution of respondents according to histological grading. Regarding histological grading was grade-II in $13(43.3 \%)$ cases,
grade-I in $11(37.7 \%)$ and grade-III in $6(20.0 \%)$ cases. The following figure is given below in detail:

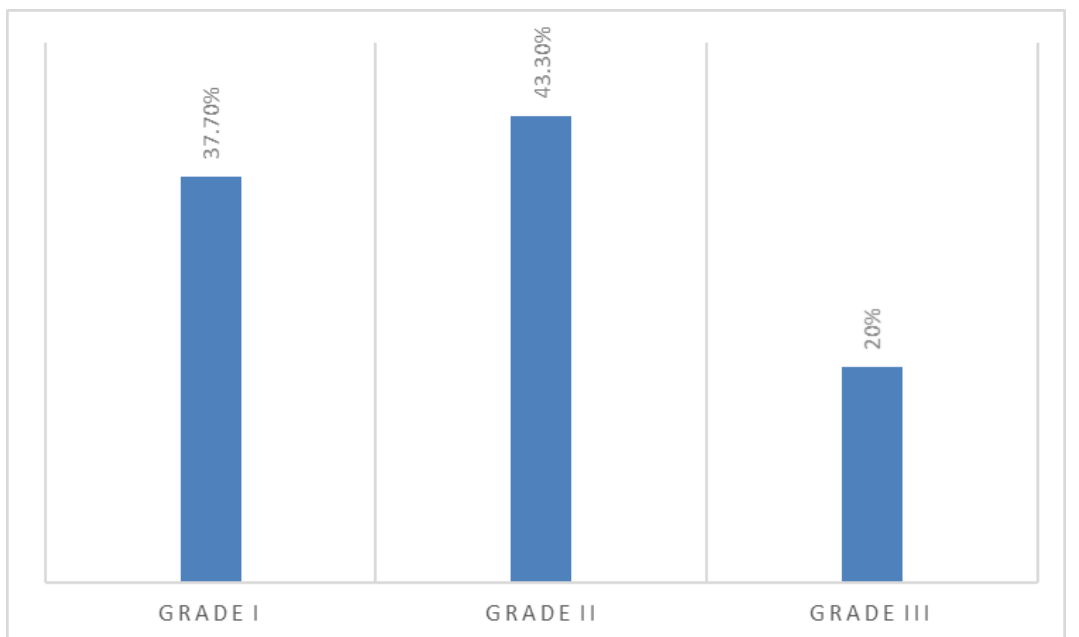

Fig-2: Distribution of respondents according to histological grading $(n=30)$

Table-2 showed the comparison of CD4+T cell count before and after chemotherapy. CD4+T cell count before chemotherapy was $1023.4 / \mathrm{uL}(\mathrm{SD} \pm 320.7)$ and CD4+T cell count after chemotherapy was $540.7 / \mathrm{uL}$
$(\mathrm{SD} \pm 266.1)$. CD4+T cell count was significantly reduced after chemotherapy $(\mathrm{z}=9.164 ; \mathrm{p}<0.001)$. The following table is given below in detail:

Table-2: Comparison of CD4+T cell count before and after chemotherapy $(n=30)$

\begin{tabular}{|l|c|c|c|}
\hline \multirow{2}{*}{ Parameter } & \multicolumn{2}{|c|}{ CD4+T cells /uL } & \multirow{2}{*}{ *p-value } \\
\cline { 2 - 3 } & Before Chemotherapy & After Chemotherapy & \\
\hline Mean & $\mathbf{1 0 2 3 . 4}$ & $\mathbf{5 4 0 . 7}$ & \multirow{3}{*}{ p $<0.001$} \\
\hline SD & $\mathbf{3 2 0 . 7}$ & $\mathbf{2 6 6 . 1}$ & \\
\hline Range & $\mathbf{4 7 6 - 1 8 7 5}$ & $\mathbf{1 2 1 - 1 0 8 1}$ & \\
\hline
\end{tabular}

$\mathrm{SD}=$ Standard deviation

*Pair-t test was applied to analysed the data.

Table-3 showed the comparison of CD8+T cell count before and after chemotherapy. CD8+T cell count before chemotherapy was $669.1 / \mathrm{uL}(\mathrm{SD} \pm 437.5)$ and
CD8+T cell count after chemotherapy was $318.5 / \mathrm{uL}$ (SD \pm 212.7). $\mathrm{CD} 8+\mathrm{T}$ cell count was significantly reduced after chemotherapy $(\mathrm{Z}=4.418 ; \mathrm{p}<0.001)$. 
Table-3: Comparison of CD8+T cell count before and after chemotherapy $(n=30)$

\begin{tabular}{|c|c|c|c|}
\hline \multirow{2}{*}{ Parameter } & \multicolumn{2}{|c|}{ CD8+T cells / uL } & \multirow{2}{*}{ *p-value } \\
\cline { 2 - 3 } & Before Chemotherapy & After Chemotherapy & \\
\hline Mean & 669.1 & 437.5 & \multirow{2}{*}{$\mathrm{p}<0.001$} \\
\hline SD & 318.5 & 212.7 & \\
\hline Range & $293-1707$ & $110-821$ & \\
\hline
\end{tabular}

$\mathrm{SD}=$ Standard deviation

*Pair-t test was applied to analysed the data.

\section{DISCUSSION}

Site of lesion of the present study is $56.7 \%$ (17 patients) in left and 43.3\% (13 patients) in right breast involvement, which is consistent with the studies done by others. One study found that the tumor were located $52 \%$ in the left side and $48 \%$ in the right side of breast [6]. Another study found $52.2 \%$ in left side and $47.8 \%$ in right side of their study patients [7]. Butother found in his observation that $76 \%$ in right side and $24 \%$ in left side of breast carcinoma patients [8] which disagree with other study[9].

In this study, histological grades were as follows- $37.7 \%$ Grade - I, $43.3 \%$ Grade - II \& $20.0 \%$ Grade- III. But various Authors show various information. As Malik I A (2002) found that $12 \%$ Grade - I, 53\% Grade - II \& 35\% Grade - III. One report described in their study as $6 \%$ Grade - I, $61 \%$ Grade- II $\& 33 \%$ Grade - III [10]. Another report found in their study, 5.3\% Grade - I, 64\% Grade - II \& 30.7\% Grade III [11]. These variations occur due to geographical presentation, genetic involvement, sample size and also for study design. In this study, family history of breast cancer was positive in $26.7 \%$ cases and no family history found in $73.3 \%$ cases.

In the study discussed here, CD4+T cell count before surgery \& chemotherapy was 1023.4 /uL (SD \pm 320.7) and CD4+T cell count during chemotherapy was $540.7 / \mathrm{uL}$ (SD \pm 266.1). CD4+T cell count was significantly reduced during chemotherapy than before $(\mathrm{z}=9.164 ; \mathrm{p}<0.001)$. And the CD8+T cell count before surgery and chemotherapy was $669.1 / \mathrm{uL}(\mathrm{SD} \pm 437.5)$ and CD8+T cell count during chemotherapy was 318.5 $/ \mathrm{uL}(\mathrm{SD} \pm 212.7)$. CD8+T cell count was significantly reduced during chemotherapy $(\mathrm{Z}=4.418 ; \mathrm{p}<0.001)$. One study showed the CD4+T cell decreased from a mean of $588 / \mathrm{mm} 3$ before chemotherapy to $105 / \mathrm{mm} 3$ during chemotherapy $(\mathrm{P}=.0002)$ and $\mathrm{C} 8+\mathrm{T}$ cells decreased from a mean of $382 / \mathrm{mm} 3$ before chemotherapy to 150 $/ \mathrm{mm} 3$ during chemotherapy $(\mathrm{P}=.0009)$ [10]. In our study, we were working on the patients undergoing adjuvant FAC protocol. The chemotherapy protocol was specific for all patients. But in Mackall et al. [11], the protocol was not specific; three different protocols were used there. Moreover, the patients also were not specific, three different categories of tumors studied there (brain tumour, sarcoma and NHL). But in our study, all patients were of breast carcinoma.

\section{CONCLUSION}

From our study we conclude that, CD4 and $\mathrm{CD} 8+\mathrm{T}$ cell number and their ratio as an assessment of immune function status in breast cancer patients, before and after surgery and adjuvant chemotherapy with the intention of delineating any potential immune aberrations that may result from therapy.

\section{REFERENCE}

1. NICRH. Annual Report 2005. Department of Cancer Epidemiology, National Institute of Cancer Research \& Hospital, Dhaka. 2005.

2. DeSaints C, Center MM, Siegel R, Jemal A. Breast Cancer Facts \& Figures 2009-10. Atlanta, USA. American Cancer Society; 2010.

3. Giuliano AE. Breast. In: Way LW, Doherty GM, editors. Current Surgical Diagnosis \& Treatment. $11^{\text {th }}$ edition. New York: McGraw Hill company; 2003: 329-331.

4. Halsted WS. The Results of Radical Operations for the Cure of Carcinoma of the Breast. Ann Surg. 1907; 46:1-19.

5. Hatam N, Ahmadloo N, Ahmad Kia Daliri A, Bastani P, Askarian M. Quality of life and toxicity in breast cancer patients using adjuvant TAC (docetaxel, doxorubicin, cyclophosphamide), in comparison with FAC (doxorubicin, cyclophosphamide, 5-fluorouracil). Arch GynecolObstet. 2011; 284:215-220.

6. Low CD4+ T lymphocyte Counts: A variety of causes and their implications to a multifactorial model of AIDS. Feb. 2001.Availabale from: http://www.virusmyth.com/aids/hiv/milowcd4.htm. Accessed on 20 Mar 2012.

7. Jatoi I, Miller AB. Why is breast cancer mortality declining? Lancet Oncol. 2003; 4:251-254.

8. Jemal A, Siegel R, Ward EM, Thun MJ. Cancer Facts \& Figures. American Cancer Society. Atlanta, USA; 2006.

9. Jemal A, Siegel R, Ward EM, Thun MJ. Cancer Facts \& Figures. Atlanta, USA; American Cancer Society, Atlanta, USA; 2008.

10. Katzung GB, Masters BS, Trevor JA. Basic and Clinical Pharmacology. $11^{\text {th }}$ ed. USA. The McGraw-Hill company; 2009.

11. Kindt JT, Goldsby AR, Osborne AB, Kuby J. Kuby- Immunology, $5^{\text {th }}$ edition. 2004. 